\title{
PERAN MANAJEMEN SARANA DAN PRASARANA DALAM MENINGKATKAN MUTU PEMBELAJARAN DI SMP ISLAM CENDEKIA CIANJUR
}

\author{
Nusi Nurstalis \\ Universitas Islam Negeri Sunan Gunung Djati Bandung \\ nusinurstalis02@gmail.com
}

\section{Tatang Ibrahim \\ Universitas Islam Negeri Sunan Gunung Djati Bandung tatangibrahim@uinsgd.ac.id}

\author{
Nandang Abdurrohim \\ Universitas Islam Negeri Sunan Gunung Djati Bandung \\ nandang.abdurohim@uinsgd.ac.id
}

\begin{abstract}
ABSTRAK
Sarana dan prasarana pendidikan merupakan salah satu penunjang proses pembelajaran. Sarana dan prasarana harus dikelola dengan baik yang dimaksudkan agar pada saat proses pembelajaran sarana dan prasarana dapat digunakan dengan optimal, efektif dan efisien, sehingga dapat menunjang dalam meningkatkan mutu pembelajaran. Pengelolaan sarana dan prasarana yang kurang optimal akan menghambat pada tercapainya tujuan yang efektif dan efisien, seperti tata kelola manajerial dalam segi inventarisasi yang belum diterapkannya sistem pengkodean pada barang, serta belum dilakukannya penghapusan pada barang yang sudah tidak dipakai dan masih ada beberapa pengelolaan yang pencatatan sarana dan prasrananya masih bersifat kondisional belum tertuang dalam bentuk tulisan. Tujuan penelitian ini adalah untuk mendeskripsikan mengenai pengelolaan sarana dan prasarana, serta untuk mengetahui peran dan upaya yang dilakukan dalam pengelolaan sarana dan prasarana untuk meningkatkan mutu pembelajaran. Penelitian ini merupakan penelitian kualitatif dengan mengambil obyek penelitian di SMP Islam Cendekia Cianjur. Pengumpulan data dilakukan melalui wawancara, observasi partisipan dan dokumentasi. Analisis data dilakukan dengan mengumpulkan, mengorganisasikan, memberikan makna pada data yang telah didapatkan, dan dari data tersebut dinarasikan dan ditarik kesimpulan. Hasil penelitian ini menggambarkan peran manajemen sarana dan prasarana di SMP Islam Cendekia Cianjur sangatlah berperan penting. Selain dapat mempermudah suatu pekerjaan, efektivitas proses belajar mengajar akan berjalan dengan baik, aman, nyaman dan bermutu. Karena tidak dapat dipungkiri sarana dan prasarana
\end{abstract}


sangat dibutuhkan baik oleh pendidik maupun peserta didik terutama dalam upaya meningkatkan mutu pembelajaran.

Kata kunci: manajemen sara dan prasarana, mutu pembelajaran

\section{ABSTRACT}

Educational facilities is one of supporting the learning process. Facilities and infrastructure must be managed properly which meant that during the learning process and infrastructure facilities can be used optimally, effective and efficient, so as to support in improving the quality of learning. Management infrastructure is less than optimal will hamper the achievement of the objectives of effective and efficient, such as the governance of managerial terms of inventory that has not been the practice of an encoding for the goods, and have not done the abolition of the goods that are not used and there are still some management that recording means and infrastructure still is conditional have not been stated in writing. The purpose of this study is to describe the management of facilities and infrastructure, and to investigate the role and efforts made in the management of facilities and infrastructure to improve the quality of learning. This research is qualitative by taking a research object in SMP Islam Cendekia Cianjur. Data collected through interviews, participant observation and documentation. Data analysis was performed by collecting, organizing, giving meaning to data that has been obtained, and from these data is narrated and drawn conclusions. The results of this study illustrate the role of infrastructure management in SMP Islam Cendekia Cianjur very important role in addition to facilitate an effective job of teaching and learning process will go well, safe, comfortable and quality.

Key words: management of infrastructure, quality of leraning

\section{PENDAHULUAN}

Pendidikan merupakan usaha sadar agar manusia dapat mengembangkan potensi dirinya melalui proses pembelajaran, hampir setiap manusia dikenai dengan pendidikan dan melaksanakan pendidikan. Sekolah memegang peranan penting dalam pendidikan karena pengaruhnya besar sekali pada jiwa anak. Dengan sekolah pemerintah mendidik bangsanya untuk menjadi seorang ahli yang sesuai dengan bidang dan bakatnya si anak didik, yang berguna bagi dirinya, berguna bagi nusa dan bangsanya (Ahmadi \& Uhbiyati, 2015, p. 180).

Manajemen adalah ilmu dan seni mengatur proses pemnfaatan sumber dya manusia dan sumber daya lainnya secara efektif dan efisien untuk mencapai suatu tujuan. Manajemen pendidikan yang berlangsung dalam suatu lembaga pendidikan berpengaruh pada tingkat kefektifan dan keefisienan pendidikan di lembaga ynag bersangkutan. Bila fungsi manajemen berjalan dengan baik dan optimal, maka pelayanan pendidikan akan berjalan dengan lancar dan memperoleh hasil yang baik (Sanusi \& Rosdiana, 2018, p. 183).

Maju mundurnya suatu bangsa sangat bergantung pada penyelenggaraan pendidikannya. Pendidikan yang baik dan bermutu maka baik dan bermutu pulalah generasi penerusnya. Indonesia saat ini memiliki jumlah penduduk yang sangat tinggi, namun berbanding terbalik dengan kualitas pendidikannya yang 
masih rendah. Hal ini menjadikan salah satu faktor semakin berkurangnya kepercayaan masyarakat terhadap pentingnya pendidikan, karena masyarakat menganggap berpendidikan atau tidak berpendidikan sama saja tidak bisa menjamin terpenuhinya kebutuhan masyarakat.

Mutu dalam pendidikan memiliki karakteristik yang khas, karena pendidikan bukanlah industri. Dalam pendidikan, produk pendidikan itu bukanlah goods (barang), tetapi services (layanan). Pemakai (pelanggan) pendidikan ada yang bersifat internal dan eksternal. Guru dan siswa adalah pemakai jasa pendidikan yang bersifat internal. Sedangkan orang tua, masyarakat dan dunia kerja adalah pemakai eksternal jasa pendidikan. Pemakai ini perlu mendapat perhatian karena mutu dalam pendidikan harus memenuhi kebutuhan, harapan dan keinginan semua pemakai (stakeholders). Dalam hal ini pemakai yang menjadi fokus utama pendidikan adalah learnears (peserta didik). Peserta didik yang menjadi alasan utama diselenggarakannya pendidikan dan peserta didik pula yang menyebabkan keberadaan lembaga maupun sistem Pendidikan (Nurdin, 2009, p. 207)

Terkait dengan hal di atas, untuk menciptakan proses pembelajaran yang bermutu maka diperlukan suasana yang kondusif, menyenangkan, efektif dan efisien, hal tersebut tidak bisa terjadi begitu saja dalam suatu lembaga pendidikan. Pelaksanaan pembelajaran yang berkualitas ditentukan oleh suatu perencanaan yang baik dalam suatu manajemen. Oleh karena itu, dalam menentukan tujuan yang baik dalam suatu lembaga pendidikan supaya menciptakan pembelajaran yang berkualitas manajemen sangat berperan penting.

Keberhasilan program pendidikan melalui proses pembelajaran sangat dipengaruhi oleh banyak faktor, salah satu diantaranya adalah tersedianya sarana dan prasarana pendidikan yang memadai disertai pemanfaatan dan pengelolaan secara optimal. Sarana dan prasarana pendidikan merupakan salah satu sumber daya yang penting dan utama dalam menunjang proses pembelajaran di sekolah, untuk itu perlu dilakukan peningkatan dalam pendayagunaan dan pengelolaannya, agar tujuan yang diharapkan dapat tercapai (Sinta, 2019).

Evaluasi merupakan kunci keberhasilan atau kegagalan suatu proses implementasi program. Karena evaluasi adalah proses pengendalian seluruh struktur organisasi program implementasi dalam melaksanakan perencanaan yang telah dibuat dan melaksanakan program. Evaluasi adalah kegiatan untuk mengukur kinerja yang sebenarnya, membandingkan dengan standar dan mengambil tindakan korektif, ketika kinerja aktual kurang dari standar dan mengambil tindakan pengembangan atau penyesuaian untuk meningkatkan kinerja jika kinerja sebenarnya adalah sama dengan atau lebih besar dari standar (Sanusi, 2020, p. 141).

Manajemen sekolah yang dapat memberikan harapan, kebutuhan dan kepuasan kepada pelanggan pendidikan dapat dikatakan sebagai sekolah yang bermutu. Sekolah yang bermutu salah satunya ditandai dengan terdapatnya fasilitas yang lengkap dan memadai. Sarana dan prasarana sangat mendukung dan memperlancar proses pendidikan. Sarana dan prasarana merupakan syarat mutlak bagi suatu lembaga pendidikan. Sarana dan prasarana pendidikan merupakan bagian yang tidak dapat terpisahkan dari proses pendidikan. Dengan 
demikian, untuk mencapai tujuan pendidikan, maka keberadaan sarana dan prasarana pendidikan tidak dapat diabaikan, melainkan harus dipikirkan untuk meningkatkan kualitas dan kuantitasnya di suatu lembaga pendidikan. Apalagi di era teknologi ini, dimana setiap lembaga pendidikan dihadapkan pada kemampuan menghadirkan sarana dan prasarana yang up date, sesuai tuntutan zaman (Kompri, 2014b, p. 238).

Sarana pendidikan adalah peralatan dan perlengkapan yang secara langsung dipergunakan dalam menunjang proses pendidikan. Prasarana pendidikan adalah fasilitas yang secara tidak langsung menunjang jalannya proses pendidikan. Sarana dan prasarana pendidikan adalah fasilitas yang digunakan untuk pelaksanaan kegiatan pendidikan dan kegiatan penunjangnya. Sarana dan prasarana tidak bisa diabaikan dalam proses pendidikan, sebab tanpa adanya sarana dan prasarana, maka pelaksanaan pendidikan tidak akan berjalan dengan baik (Kompri, 2014b, p. 193)

Sarana pendidikan sebagai segala macam alat yang digunakan secara langsung dalam proses pendidikan. Sementara prasarana pendidikan adalah segala macam alat yang tidak secara langsung digunakan dalam proses pendidikan. Erat terkait dengan sarana dan prasarana pendidikan itu, dalam daftar istilah pendidikan dikenal pula sebutan alat bantu pendidikan (teaching aids), yaitu segala macam peralatan yang dipakai guru untuk membantunya memudahkan melakukan kegiatan mengajar. Alat bantu pendidikan ini yang pas untuk disebut sebagai sarana pendidikan. Jadi sarana pendidikan adalah segala macam peralatan yang digunakan untuk memudahkan penyampaian materi pelajaran. Jika dilihat dari sudut pandang murid, sarana pendidikan adalah segala macam peralatan yang digunakan murid untuk memudahkan mempelajari mata pelajaran (Kompri, 2014a, p. 234)

Prasarana pendidikan adalah segala macam peralatan, kelengkapan, dan benda-benda yang digunakan guru dan murid untuk memudahkan penyelenggaraan pendidikan. Perbedaan sarana pendidikan dan prasarana pendidikan adalah pada fungsi masing-masing, yaitu sarana pendidikan untuk memudahkan penyampaian/mempelajari materi pelajaran, sedangkan prasarana pendidikan untuk memudahkan penyelenggaraan pendidikan. Dalam makna inilah sebutan digunakan langsung dan digunakan tidak langsung dalam proses pendidikan seperti telah disinggung sebelumnya (Kompri, 2014a, p. 234)

Pembicaraan mengenai sarana dan prasarana pendidikan dalam dunia pendidikan di Indonesia sendiri selalu bersamaan dengan upaya perbaikan mutu pendidikan itu sendiri. Karenanya dalam pasal 45 ayat (1) Undang-Undang Sistem Pendidikan Nasional dijelaskan bahwa setiap satuan pendidikan formal dan non formal menyediakan sarana dan prasarana yang memenuhi keperluan pendidikan sesuai dengan pertumbuhan dan perkembangan potensi fisik, kecerdasan intelektual, sosial, emosional, kejiwaan peserta didik.

Manajemen sarana prasarana menjadi sebuah kegiatan yang mesti dilakukan pada sebuah lembaga pendidikan untuk mendukung keberlangsungan kegiatan belajar mengajar (Supiana et al., 2018). Manajemen sarana dan prasarana adalah kegiatan yang mengatur untuk mempersiapkan seagala peralatan/material bagi terselenggaranya proses pendidikan di sekolah (Rohiat, 2006). Manajemen sarana dan prasarana dibutuhkan untuk membantu kelancaran proses belajar mengajar. Manajemen sarana dan prasarana dapat 
diartikan sebagai kegiatan menata, mulai dari merencanakan kebutuhan, pengadaan, penyimpanan dan penyaluran, pendayagunaan, pemeliharaan dan penginventarisan dan penghapusan serta penataan lahan, bangunan, perlengkapan, dan perabot sekolah serta tepat guna dan tepat sasaran (Nurbaiti, 2015).

Agar program pendidikan bisa tercapai dengan baik ada beberapa prinsip yang harus diperhatikan dalam mengelola sarana dan prasarana pendidikan di sekolah. Prinsip-prinsip yang dimaksud adalah prinsip pencapaian tujuan, efisiensi, administratif, kejelasan tanggung jawab dan kekohesifan. Dalam hal prinsip pencapaian tujuan, bahwa sarana dan prasarana pendidikan disekolah harus selalu dalam kondisi siap pakai bilamana akan didayagunakan. Sedangkan prinsip efisiensi, yaitu bahwa pengadaan sarana dan prasarana pendidikan di sekolah harus dilakukan melalui perencanaan yang seksama, sehingga dapat diadakan sarana dan prasarana pendidikan yang baik dengan harga yang murah, dan pemakaiannya pun harus dengan hati-hati sehingga mengurangi pemborosan. Prinsip ketiga adalah administratif, yaitu bahwa manajemen sarana dan prasarana pendidikan di sekolah harus selalu memperhatikan undangundang, peraturan, instruksi dan petunjuk teknis yang diberlakukan oleh yang berwenang. Untuk prinsip kejelasan tanggung jawab, maknanya bahwa manajemen sarana dan prasarana pendidikan di sekolah harus di delegasikan kepada personel sekolah yang mampu bertanggungjawab. Dan prinsip yang terakhir adalah kekohesifan, yaitu bahwa manajemen sarana dan prasarana pendidikan disekolah itu harus direalisasikan dalam bentuk proses kerja yang sangat kompak (Prastyawan, 2016).

Perencanaan sarana dan prasarana pendidikan merupakan proses perancangan upaya pembelian, penyewaan, peminjaman, penukaran, daur ulang, rekondisi/rehabilitas, distribusi atau pembuatan peralatan dan perlengkapan yang sesuai dengan kebutuhan sekolah. Proses ini di awali diantaranya dengan analisis kebutuhan sarana dan prasarana pendidikan serta proyeksi kebutuhan sarana dan prasarana Pendidikan

Analisis kebutuhan sarana dan prasarana ini dilakukan untuk mengetahui kebutuhan sarana dan prasana pendidikan pada suatu unit kerja diperlukan data dan informasi tentang sarana dan prasana pendidikan, baik sarana dan prasana pendidikan yang ada dilapangan maupun yang seharusnya ada sesuai dengan kententuan yang berlaku. Analisis merupakan kegiatan membandingkan antara data yang ada dilapangan dengan data yang seharusnya ada menurut pembakuan sarana dan prasana pendidikan. Hasil analisis akan bertumpu pada dua informasi, yaitu informasi tentang ada kesesuaian dan tidak ada kesesuaian. Jika analisis menghasilkan informasi tidak ada kesesuaian, maka ada dua kemungkinan yaitu sarana dan prasana keadaannya kurang atau keadaannya berlebih. Jika keadaan sarana dan prasana kurang, maka hal ini berarti ada kebutuhan terhadap sarana dan prasana pendidikan. Kebutuhan sarana dan prasana pendidikan dapat pula ditentukan berdasarkan data hasil proyeksi penduduk usia sekolah yang akan masuk menjadi siswa baru.

Proyeksi kebutuhan sarana dan prasarana pendidikan didasarkan kepada kebutuhan sarana dan prasarana pendidikan sesuai keadaan data pada masa lalu dan masa kini, perencanaan sarana dan prasarana pendidikan juga dapat dilakukan berdasarkan data pada masa yang akan datang sebagai hasil 
proyeksi. Proyeksi kebutuhan sarana dan prasarana pendidikan di masa depan mencakup berbagai pertimbangan. Mungkin membutuhkan keahlian teknik yang tinggi diluar kemampuan ahli perencana pendidikan. Meskipun demikian adalah tugas perencana pendidikan untuk mengetahui informasi penting apa saja yang dibutuhkan dalam rangka pembangunan atau mengkonstruksi gedung sekolah dan saran lainnya. Ini akan berkaitan langsung dengan informasi mengenai fasillitas sekolah yang harus dikumpulkan dan disediakan untuk memberikan pelayanan secara langsung kepada perencana, perumus pembiayaan dan pengkonstruksi fasilitas sekolah. Tugas perencana dalam hal ini adalah mengumpulkan data untuk menentukan persediaan sarana pendidikan yang ada saat ini berdasarkan jenis dan jenjang pendidikan, termasuk bagaimana kualitasnya. Untuk itu, perencana dapat melakukan survei pendidikan yang ada disekolah-sekolah. Data hasil survei tersebut kemudian dibandingkan dengan kententuan atau standar-standar yang sudah ditentukan guna memperoleh informasi apakah sarana dan prasana yang ada disekolah-sekolah tersebut kondisinya baik atau buruk.

Pengadaaan sarana dan prasana pendidikan adalah kegiatan penyediaan semua jenis sarana dan prasarana sesuai dengan kebutuhan dalam rangka mencapai tujuan pendidikan yang telah ditetapkan sebelumnya. Dalam konteks persekolahan, pengadaan sarana dan prasana pendidikan merupakan segala kegiatan yang dilakukan dengan cara menyediakan semua keperluan barang atau jasa berdasarkan hasil perencanaan dengan maksud untuk menunjang kegiatan pembelajaran agar kegiatan pembelajaran dapat berjalan secara efektif dan efisien sesuai dengan tujuan yang diinginkan.

Ada beberapa alternatif cara dalam pengadaan sarana dan prasarana pendidikan persekolahan. Beberapa alternatif cara pengadaan sarana dan prasarana pendidikan persekolahan tersebur adalah melalui membeli, membuat sendiri, bantuan atau hibah, menyewa, meminjam, mendaur ulang, menukar serta memperbaiki atau merekontruksi kembali.

Pengawasan merupakan salah satu fungsi manajemen yang harus dilaksanakan oleh pimpinan organisasi. Berkaitan dengan sarana dan prasarana pendidikan di sekolah, perlu adanya control baik dalam pemeliharaan atau pemberdayaan. Pengawasan (control) terhadap sarana dan prasarana pendidikan di sekolah merupakan usaha yang ditempuh oleh pimpinan dalam membantu personel sekolah untuk menjaga atau memelihara, dan memanfaatkan sarana dan prasarana sekolah dengan sebaik mungkin demi keberhasilan proses pembelajaran di sekolah (Nurabadi, 2014).

Penyimpanan adalah kegiatan yang dilakukan untuk menampung hasil pengadaan barang milik negara (baik hasil pembelian, hibah, hadiah) pada wadah/tempat yang telah disediakan. Penyimpanan sarana pendidikan adalah kegiatan simpan menyimpan suatu barang baik berupa perabot, alat tulis kantor, surat-surat maupun barang elektronik dalam keadaan baru, maupun rusak yang dapat dilakukan oleh seorang atau beberapa orang yang ditujukan atau ditugaskan pada lembaga pendidikan.

Inventarisasi sarana dan prasarana pendidikan adalah kegiatan pencatatan atau pendaftaran barang-barang milik lembaga (sekolah) ke dalam suatu daftar inventaris barang secara tertib dan teratur menurut ketentuan dan tata cara yang berlaku. Barang inventaris sekolah adalah semua barang milik 
negara (yang dikuasai sekolah) baik yang diadakan/dibeli melalui dana pemerintah, komite sekolah dan masyarakat, maupun yang diperoleh sebagai pertukaran, hadiah atau hibah serta hasil usaha pembuatan sendiri sekolah guna menunjang proses belajar mengajar.

Pemeliharaan sarana dan prasarana pendidikan adalah kegiatan untuk melaksanakan pengurusan dan pengaturan sarana dan prasarana agar semua sarana dan prasarana tersebut selalu dalam keadaan baik dan siap untuk digunakan secara berdaya guna dan berhasil guna dalam mencapai tujuan pendidikan. Pemeliharaan merupakan kegiatan penjagaan atau pencegahan dari kerusakan suatu barang, sehingga barang tersebut kondisinya baik dan siap digunakan.

Pemeliharaan mencakup segala daya upaya yang terus menerus untuk mengusahakan agar sarana dan prasarana tetap dalam keadaan baik. Kegiatan pemeliharaan dimulai dari pemakaian barang, yaitu dengan cara hati-hati dalam menggunakannya. Pemeliharaan yang bersifat khusus harus dilakukan oleh petugas yang mempunyai keahlian khusus pula sesuai dengan jenis barang yang dimaksud.

Penghapusan sarana dan prasarana pendidikan merupakan kegiatan pembebasan sarana dan prasarana pendidikan dari pertanggungjawaban yang berlaku dengan alasan yang dapat dipertanggungjawabkan. Secara lebih operasional penghapusan sarana dan prasarana pendidikan adalah merupakan proses kegiatan yang bertujuan untuk mengeluarkan atau menghilangkan sarana dan prasarana pendidikan dari inventaris barang karena sarana dan prasarana tersebut sudah dianggap tidak berfungsi sebagaimana yang diharapkan terutama untuk kepentingan pelaksanaan pembelajaran di sekolah.

Penghapusan sarana dan prasarana pendidikan dilakukan berdasarkan peraturan perundang-undangan yang berlaku. Dalam pelaksanaannya, harus mempertimbangkan alasan-alasan normatif tertentu karena muara dari berbagai pertimbangan tersebut tidak lain adalah demi efektifitas dan efisiensi kegiatan pendidikan di sekolah.

Sekolah dikatakan bermutu apabila menghasilkan output/lulusan yang berkualitas, maka diperlukan suatu pengelolaan pada setiap komponenkomponen sekolah salah satunya adalah sarana dan prasarana sekolah (Munir \& Karwanto, 2014). Terkait dengan mutu pendidikan, terdapat lima komponen yang menentukan mutu pendidikan yaitu kegiatan belajar mengajar, manajemen pendidikan yang efektif dan efisien, buku dan sarana belajar yang memadai dan selalu dalam kondisi siap pakai, fisik dan penampilan sekolah yang baik, serta partisipasi aktif masyarakat (Bafadal, 2003).

Proses belajar mengajar yang bermutu adalah proses yang dapat meningkatkan pengetahuan dan kemampuan siswa secara optimal. Untuk melaksanakan proses belajar mengajar tersebut, tentunya tidak dapat terlepas dari fasilitas pendukungnya seperti media belajar, ruang belajar yang nyaman, tersedia perpustakaan, laboratorium, dan sebagainya.

SMP Islam Cendekia Cianjur adalah lembaga pendidikan berbasis Islam yang memiliki visi menciptakan peserta didik yang unggul dan terdepan dalam menghasilkan cendekiawan muslim yang religius, kreatif dan produktif dan berbudaya lingkungan serta hidup sehat. Untuk membangun dan mengembangkan potensi akademik peserta didik dalam rangka 
mengembangkan kecerdasannya, peserta didik dibekali dengan keterampilan dalam bidang teknologi dan sains. Selain itu, dalam setiap kegiatan pendidikan selalu diterapkan nilai-nilai Islam sehingga diharapkan peserta didik berlaku sesuai dengan syariat Islam dan menumbuhkan kepribadian yang berakhlakul karimah, dapat membuka cakrawala pandang sebagai bagian dari masyarakat dunia serta menanamkan toleransi dan melaksanakan program pegembangan lingkungan hidup dan sekolah sehat.

SMP Islam Cendekia Cianjur merupakan salah satu sekolah Islam unggulan yang ada di Kabupaten Cianjur yang memiliki sarana dan prasarana sekolah yang sangat lengkap, modern, dan nyaman yang dapat menciptakan suasana sekolah yang kondusif, menyenangkan, efektif dan efisien.

Berdasarkan fenomena di atas ada beberapa hal yang menarik untuk diteliti mengenai peran manajemen sarana dan prasara dalam meningkatkan mutu pembelajaran di SMP Islam Cendekia Cianjur. Sehingga peneliti tertarik untuk menggali informasi seputar bagaimana pelaksanaan, peran, faktor pendukung serta penghambat dalam melaksanakan manajemen sarana dan prasarana di SMP Islam Insan Cendekia Cianjur.

\section{METODE}

Penelitian ini menggunakan pendekatan fenomenologi dengan jenis penelitian deskriptif kualitatif. Metode kualitatif merupakan prosedur penelitian yang menggunakan data deskriptif berupa kata-kata tertulis atau lisan dari orangorang dan perilaku yang diamati (Moleong, 2011). Metode penelitian yang digunakan adalah studi pustaka dan studi lapangan yang diurai secara deskriptif. Langkah-langkah yang akan dilakukan dalam penelitian ini meliputi menentukan pendekatan data dan metode penelitian, menentukan jenis dan sumber data penelitian, menentukan teknik pengumpulan data, serta menentukan teknik analisis data. Teknik pengumpulan data dilakukan melalui wawancara, observasi partisipan dan dokumentasi. Sedangkan untuk teknik analisis data dilakukan melalui unitisasi data, kategorisasi data dan penafsiran data.

\section{HASIL DAN PEMBAHASAN \\ Manajemen Sarana dan Prasarana di SMP Islam Cendekia Cianjur}

Perencanaan

Perencanaan sarana dan prasarana yang dilakukan di SMP Islam Cendekia Cianjur pertama-tama mengidentifikasi kebutuhan sarana dan prasarana untuk berlangsungnya kegiatan di sekolah, baik kebutuhan kantor maupun kebutuhan untuk pembelajaran. Adapun selain itu perencanaan juga melihat sarana dan prasarana yang sudah ada dengan melakukan pengecekan/pemeriksaan sisa barang yang telah dipakai, dengan menambahnya sesuai kebutuhan sekolah. Pelaksanaan perencanaan sarana dan prasarana di SMP Islam Cendekia Cianjur telah berkoordinasi dengan para guru. Setiap ruangan diberikan tanggung jawabnya kepada guru mata pelajaran masing-masing, jadi untuk perencanaan sarana dan prasarana di akomodir terlebih dahulu, tidak setiap ada kekurangan langsung di ajukan, kecuali kebutuhan sarana dan prasarana yang bersifat emergency maka dapat diajukan secara langsung. 
Proses perencanaan dilakukan oleh unit-unit yang ada di Yayasan Pribadi Kamila Cianjur, yang meliputi pihak yayasan, kepala sekolah, wakil kepala sekolah bidang sarana dan prasarana (Waka Sarpras), guru yang terlibat, dan bendahara sekolah. Perencanaan dibuat serinci mungkin sesuai dengan apa yang dibutuhkan sekolah baik untuk proses pembelajaran maupun untuk kebutuhan kantor. Akan tetapi dalam pelaksanaannya tergantung pada dana yang tersedia di Yayasan Pribadi Kamila Cianjur.

Mekanisme perencanaannya dari sekolah mengusulkan rencana kegiatan/program kepada Yayasan Pribadi Kamila Cianjur. Waka Sarpras mengidentifikasi kebutuhan barang, setelah mengidentifikasi kebutuhan yang diperlukan dibuat proposal pengajuan kebutuhan barang bersama bagian administrasi/bendahara juga berkoordinasi dengan kepala sekolah. Setelah itu proposal diajukan kepada kepala sekolah, jika proposal disetujui maka Waka Sarpras ditemani dengan anggotanya membeli peralatan yang dibutuhkan sesuai dengan proposal yang telah disetujui. Untuk pembelian barang yang ringan seperti peralatan akademik dan peralatan inventarisasi kantor dapat disetujui langsung oleh kepala sekolah, namun untuk pembelian barang seperti AC, komputer dan alat berat yang lainnya harus melalui persetujuan pihak Yayasan Pribadi Kamila Cianjur.

Pengadaan

Prosedur dalam pengadaan meliputi perencanaan, pelaksanaan dan pelaporan. Pengadaan dilaksanakan sesuai dengan perencanaan yang telah ditentukan dalam proses penyusunan program dan anggaran. Pelaksanaan pengadaan barang pertama-tama Waka Sarpras berkoordinasi dengan para guru untuk menganalisa apa saja kebutuhan yang dibutuhkan untuk proses belajar mengajar, selain itu untuk kebutuhan kantor di analisa langsung oleh Waka Sarpras. Setelah di analisa dibuat proposal berkoordinasi dengan kepala sekolah.

Adapun mekanisme pelaksanaan pengadaan sarana dan prasarana di SMP Islam Cendekia Cianjur adalah proposal yang telah dibuat disetujui/ditindak lanjuti oleh kepala sekolah, kemudian Waka Sarpras mengadakan rapat koordinasi dengan bagian administrasi, dan kepala sekolah untuk memilih atau menunjuk seseorang baik dari bagian administrasi/pegawai dan staf sekolah lainnya untuk melaksanakan pembelian barang.

Dalam prosedur pelaporan barang, pertama dilakukan pemeriksaan barang yang telah dibeli, apabila barang tidak sesuai kualitas ataupun tidak sesuai dengan kebutuhan maka barang akan dikembalikan yang tentunya pada saat pembelian barang pembeli telah bersepakat dengan penjual jika barangnya tidak sesuai dengan kebutuhan akan dikembalikan untuk kemudian diganti. Waka Sarpras bertanggung jawab untuk membuat LPJ (laporan pertanggungjawaban) pembelian/pengadaan barang dan dilaporkan. Kemudian barang di list dalam buku pembelian barang/bahan.

\section{Pengawasan}

Pelaksanaan pengawasan sarana dan prasarana di SMP Islam Cendekia Cianjur dilakukan oleh semua pihak yang ada di lingkungan sekolah. Semua pihak terlibat untuk menjaga sarana dan prasarana yang ada disekolah, ketika terjadi kerusakan/kehilangan, orang pertama yang melihat akan segera 
melaporkan sarana dan prasarana yang rusak tersebut, kemudian Waka Sarpras membuat berita acara untuk barang yang rusak/hilang sehingga pihak yang bertanggung jawab akan mengganti barang yang hilang atau rusak tersebut.

Upaya pengawasan sarana dan prasarana sekolah dilakukan dengan memberikan petunjuk atau cara pakai barang-barang agar pemakaian barang sesuai dengan fungsinya atau didampingi oleh pembina atau guru yang bertanggung jawab, sehingga barang yang dipakai tidak mudah rusak. Pengawasan juga dilakukan dengan pengecekkan barang secara rutin oleh para petugas non kependidikan terutama seperti barang-barang elektronik pengawasan dilakukan oleh petugas khusus secara rutin, sehingga menjamin ketersediaan sarana dan prasarana tersebut ketika dibutuhkan.

Adapun pelaksanaan pengawasan yang dilakukan oleh Waka Sarpras, yaitu dengan mengawasi sejauh mana perkembangan pengolaan yang dilakukan dan memberikan pengarahan untuk pengelolaan yang lebih baik.

\section{Inventarisasi}

Inventarisasi dilakukan secara periodik, hal ini diharapkan agar dengan adanya inventarisasi sarana dan prasarana yang ada dapat teradministrasi dengan rapi, mempermudah penemuan barang, dan lebih terawasi. Namun sayangnya di SMP Islam Cendekia Cianjur sarana dan prasarana yang sudah di list dalam buku inventarisasi belum ditandai atau di beri kode untuk setiap sarana dan prasarana yang ada di dalam daftar list inventarisasi. Kemudian untuk barang-barang yang rusak disimpan di gudang.

Sarana prasarana yang ada dicatat seperti daftar inventaris kelas (meja, kursi, AC, dan semua barang yang ada di dalam kelas) atau daftar inventaris yang ada di ruang kepala sekolah. Selain itu pun untuk barang yang tidak bergerak maupun bergerak semua tercatat dalam buku inventaris, hanya saja belum ada pengkodean barang inventaris.

\section{Penyimpanan}

Penyimpanan barang dilakukan setelah barang sudah diterima dan diperiksa kemudian di catat dalam buku inventaris. Sarana dan prasarana yang ada kemudian di simpan/diberikan seperti kepada wali kelas atau bidang-bidang tertentu untuk disimpan dan digunakan sesuai dengan kebutuhan. Penyimpanan sarana dan prasarana dilakukan sesuai dengan tempatnya masing-masing seperti alat-alat laboratorium di simpan di ruang laboratorium, begitu juga dengan yang lainnya.

\section{Pemeliharaan}

Pemeliharaan di SMP Islam Cendekia Cianjur pada setiap unit sarana dan prasarana telah meliki petugas-petugas tertentu terutama pada sarana dan prasarana yang berat seperti sound system, AC, komputer dan lainnya sehingga pelaksanaan pemeliharaan dapat dilakukan dengan berkoordinasi dengan petugas-petugas yang telah ditentukan tersebut, sehingga ketika ada kerusakan petugas dapat langsung melaporkan kepada Waka Sarpras. Ataupun sarana dan prasarana lainnya seperti barang-barang yang ada di kelas kebutuhan pembelajaran itu merupakan tanggung jawab wali kelas, sehingga pemeliharaan dilakukan oleh yang bertanggung jawab tersebut ketika ada kekurangan atau 
kerusakan maka dapat diajukan kepada Waka Sarpras. Dengan demikian pemeliharaan dilakukan agar sarana dan prasarana yang dibutuhkan untuk proses kegiatan di sekolah terutama dalam proses pembelajaran dapat berjalan lancar.

\section{Penghapusan}

Terdapat kesenjangan antara teori dengan hasil yang ada dilapangan, di SMP Islam Cendekia Cianjur dalam pengelolaan sarana dan prasarana belum adanya proses penghapusan, sehingga barang-barang yang sudah tidak dipakai hanya disimpan di Gudang.

\section{Peran Manajemen Sarana dan Prasarana dalam Meningkatkan Mutu Pembelajaran di SMP Islam Cendekia Cianjur}

SMP Islam Cendekia Cianjur merupakan sekolah unggulan yang didirikan untuk memenuhi kebutuhan dan harapan masyarakat. SMP Islam Cendekia Cianjur adalah sekolah yang memiliki fasilitas lengkap dan modern guna menunjang pembelajaran yang bermutu sehingga dapat menghasilkan peserta didik yang memiliki kompetensi sesuai yang diharapkan oleh para orang tua, sehingga kebutuhan, harapan, dan keinginan para orang tua bisa terpenuhi. Selain fasilitas yang ada, guru merupakan salah satu fasilitator menuju tercapainya mutu pembelajaran yang baik dan efektif, sebagaimana program pembelajaran yang ada di SMP Islam Cendekia Cianjur seperti program tambahan jam belajar yaitu project best learning, sekolah merekrut guru-guru terbaik untuk mengajarkan pembelajaran kepada peserta didik. Dilengkapi dengan fasilitas alat-alat project sehingga dapat menunjang pembelajaran yang efektif dan bermutu, hal ini dapat dilihat dari nilai hasil pembelajaran peserta didik yang semakin meningkat terutama pada nilai psikomotorik dan prestasi yang diraih oleh peserta didik saat mengikuti perlombaan. Sejauh ini telah banyak sekali karya yang di ciptakan oleh peserta didik SMP Islam Cendekia Cianjur ini salah satunya seperti membuat makanan yang diberikan nama nata de alu yang terbuat dari tanaman lidah buaya, kemudian membuat lampu hias, tinta organik yang digunakan pada white board yang dibuat dari tanaman alang-alang, dry shampoo yang terbuat dari toge, membuat kertas dari kulit kuaci, menanam tanaman hidroponik dan masih banyak lain hasil karya yang sudah dibuat oleh peserta didik.

SMP Islam Cendekia Cianjur memiliki banyak sekali sarana dan prasarana yang dapat menunjang berkembangnya bakat peserta didik, seperti studio musik yang dilengkapi dengan alat-alat musik, baik alat musik klasik maupun alat musik modern, lapangan serbaguna dilengkapi alat-alat olah raga, laboratorium komputer, laboratorium sains dengan alat-alat praktikum seperti Kit Mekanika, Kit Listrik dan Magnet, Kit Hidrostatika dan Panas, Kit Optika dan masih banyak lagi alat praktikum yang lainnya. Adapun sarana penunjang lainnya seperti SICC mart, kantin, finger print untuk siswa dan guru, kondisi ruang kelas yang nyaman, sarana toilet yang melebihi standar yang telah ditentukan, lingkungan sekolah yang nyaman, indah dan bersih dan masih banyak lagi sarana penunjang lainnya.

Agar terciptanya kegiatan belajar mengajar yang nyaman, efektif dan efisien penunjang proses belajar mengajarpun harus dilengkapi dengan 
fasilitas/sarana dan prasarana yang disesuaikan dengan standar yang telah di tentukan oleh pemerintah. Di SMP Islam Cendekia Cianjur terdapat 17 rombongan belajar dengan memiliki kelas 3 lantai berukuran $8 \times 9$ meter. Satu kelas tidak lebih dari 26 peserta didik difasilitasi dengan satu meja dan satu kursi untuk setiap peserta didik, disetiap ruang terdapat AC, LCD Proyektor, satu meja guru dan kursi, lemari dan peralatan belajar mengajar lainnya. Kondisi ruang belajar di SMP Islam Cendekia Cianjur sudah lebih dari standar minimum sebagaimana yang telah ditetapkan oleh pemerintah dengan adanya kelengkapan sarana prasarana ini menjadi penunjang kegiatan belajar yang sangat nyaman, kondusif, efektif dan efisien. Dengan begitu kegiatan pembelajaran di SMP Islam Cendekia Cianjur akan menciptakan pembelajaran yang bermutu karena ditunjang oleh fasilitas yang lengkap.

Dengan adanya fasilitas yang lengkap tersebut dapat mendorong peserta didik agar bisa menumbuhkan potensi yang ada dalam dirinya dan mampu bersaing dengan yang lain. Selain itu membuat suasana pembelajaran lebih hidup, peserta didik lebih aktif dan bersemangat sekalipun pembelajaran tersebut sangat sulit tetapi peserta didik sangat antusias saat belajar. Hal ini berbeda ketika tidak ada fasilitas tersebut, peserta didik kurang bersemangat mengingat pembelajaran yang sulit, yang pada akhirnya hanya membuat peserta didik kebingngan.

Sehingga dapat disimpulkan tanpa adanya fasilitas yang mendukung program tersebut suatu pembelajaranpun tidak akan berjalan dengan efektif. Hal ini berkaitan dengan layanan yang diberikan, layanan yang yang baik dan berkualitas berbanding lurus dengan layanan yang didapatkan yang mampu memenuhi kebutuhan, harapan dan keinginan pelanggan, sehingga menghasilkan output yang berkualitas dan kebutuhan masyarakat dapat terpenuhi.

Manajemen sangat berperan dalam setiap kegiatan yang dilakukan demi mencapai suatu tujuan yang efektif dan efisien. Pemenuhan fasilitas/sarana dan prasarana disuatu sekolah akan sangat menunjang dalam menciptakan pembelajaran yang bermutu, meskipun dalam pengelolaannya terdapat kesenjangan antara teori dengan hasil yang didapatkan dilapangan, di SMP Islam Cendekia Cianjur sarana dan prasarana baik yang menunjang secara langsung dalam proses pembelajaran maupun sarana dan prasarana yang tidak langsung menunjang proses pembelajaran sudah sangat lengkap dan bagus, meskipun secara administrasi kegiatan manajemen sarana dan prasarana belum efektif dilakukan seperti belum adanya proses manajemen sarana dan prasarana berupa inventarisasi yang dibuat kode barang, belum adanya kegiatan penghapusan untuk sarana dan prasarana yang sudah tidak digunakan, dan masih terdapat administrasi manajemen sarana dan prasarana yang memang belum dilakukan SMP Islam Cendekia Cianjur. Namun hal ini tidak menjadi hambatan terhadap mutu pembelajaran, karena meskipun kegiatan manajemen sarana dan prasarana yang dilakukan belum menyeluruh dan maksimal proses pembelajaran tetap berjalan dengan efektif dan bermutu hal ini dapat dibuktikan melalui prestasi yang diraih oleh para peserta didik. Hal ini merupakan prestasi yang sangat bagus, sekolah mampu memberdayakan SDM yang ada, yang bahkan SDM yang ada bukan ahli di bidang manajemen, hal ini dipengaruhi oleh faktor-faktor tertentu salah satunya dengan ketersediaan keuangan yang cukup 
sehingga sekolah bisa menyediakan fasilitas yang lengkap demi memenuhi kebutuhan peserta didik dalam proses pembelajaran sehingga dapat menghasilkan pembelajaran yang bermutu.

\section{SIMPULAN}

Manajemen merupakan kegiatan yang sangat penting yang harus dilakukan dalam sebuah pengelolaan pendidikan terutama dalam pengelolaan sarana dan prasarana pendidikan yang menunjang dalam proses peningkatan mutu pembelajaran. Dalam meningkatkan mutu pembelajaran sarana dan prasarana sangatlah berperan penting, dengan adanya sarana dan prasarana yang mendukung, proses pembelajaran akan lebih mudah disampaikan, meningkatkan semangat belajar peserta didik, dan tercapainya proses pembelajaran yang bermutu sehingga menghasilkan output yang berkualitas. Ketersediaan sarana dan prasarana yang lengkap berbanding lurus dengan ketercapaian mutu pembelajaran yang ditandai dengan meningkatnya prestasi yang didapatkan oleh peserta didik. Hasil penelitian ini menunjukkan peran manajemen sarana dan prasarana di SMP Islam Cendekia Cianjur sangatlah berperan penting. Selain dapat mempermudah suatu pekerjaan, efektivitas proses belajar mengajar akan berjalan dengan baik, aman, nyaman dan bermutu. Karena tidak dapat dipungkiri sarana dan prasarana sangat dibutuhkan baik oleh pendidik maupun peserta didik terutama dalam upaya meningkatkan mutu pembelajaran.

\section{REFERENSI}

Ahmadi, A., \& Uhbiyati, N. (2015). Ilmu Pendidikan. PT Rineka Cipta.

Bafadal, I. (2003). Manajemen Perlengkapan Sekolah (Teori dan Aplikasinya). Bumi Aksara.

Kompri, K. (2014a). Manajemen Pendidikan 2. Alfabeta.

Kompri, K. (2014b). Manajemen Sekolah Teori dan Praktik. Alfabeta.

Moleong, Lexy. J. (2011). Metodologi Penelitian Kualitatif. PT. Remaja Rosda Karya.

Munir, M., \& Karwanto. (2014). Manajemen Sarana Dan Prasarana Dalam Upaya Peningkatan Mutu Pendidikan Di SMA Negeri 12 Surabaya. Jurnal Inspirasi Manajemen Pendidikan, 4(4), 134-140.

Nurabadi, A. (2014). Manajemen Sarana dan Prasarana Pendidikan. Fakultas Ilmu Pendidikan Universitas Negeri Malang.

Nurbaiti, N. (2015). Manajemen Sarana dan Prasarana Sekolah. MAPEN: Jurnal Manajer Pendidikan, 9(4), 536-546.

Nurdin, D. (2009). Kepemimpinan Mutu Pendidikan (Konsep dan Aplikasi Menuju Kepemimpinan Sekolah Produktif). PT Sarana Panca Karya Nusa.

Prastyawan, P. (2016). Manajemen Sarana dan Prasarana Pendidikan. AlHikmah: Jurnal Studi Keislaman, 6(1), 33-46. https://doi.org/10.36835/hjsk.v6i1.2797

Rohiat, R. (2006). Manajemen Sekolah (Teori Dasar dan Praktik). Refika Aditama. 
N. Nurstalis, T. Ibrahim, N. Abdurrohim

Sanusi, H. P. (2020). Madrasah Quality Improvement Evaluation Strategic

Management Based. International Journal of Nusantara Islam, 8(2), 137145. https://doi.org/10.15575/ijni.v8i2.10510

Sanusi, H. P., \& Rosdiana, F. (2018). Manajemen Strategi Kepemimpinan Kepala Kantor Kementerian Agama Kabupaten Garut. Jurnal Isema : Islamic Educational Management, 3(2), 181-192.

https://doi.org/10.15575/isema.v3i2.5010

Sinta, I. M. (2019). Manajemen Sarana Dan Prasarana. Jurnal Isema : Islamic Educational Management, 4(1), 77-92. https://doi.org/10.15575/isema.v4i1.5645

Supiana, S., Hermawan, A. H., \& Hilmy, M. F. (2018). Manajemen Sarana Dan Prasarana Diniyah Takmiliyah. Jurnal Isema: Islamic Educational Management, 3(2), 23-41. https://doi.org/10.15575/isema.v3i2.5007 